\title{
Aztreonam (for inhalation solution) for the treatment of chronic lung infections in patients with cystic fibrosis: an evidence-based review
}

This article was published in the following Dove Press journal:

Core Evidence

10 August 2011

Number of times this article has been viewed

\author{
Stephen Kirkby' \\ Kimberly Novak ${ }^{2}$ \\ Karen McCoy' \\ 'Section of Pulmonary Medicine, \\ Nationwide Children's Hospital, \\ ${ }^{2}$ Department of Pharmacy, \\ Nationwide Children's Hospital, \\ Ohio State University College \\ of Medicine, Columbus, $\mathrm{OH}$, USA
}

Correspondence: Stephen Kirkby Section of Pulmonary Medicine, Nationwide Children's Hospital, Ohio State University College of Medicine, 700 Children's Drive, Columbus, $\mathrm{OH} 43205$, USA

$\mathrm{Tel}+\mathrm{I} 6$ I4 7224766

Fax + I 614722 4755

Email stephen.kirkby@ nationwidechildrens.org

\begin{abstract}
Cystic fibrosis (CF) is a genetic disease caused by abnormal chloride transport across cellular membranes. In the respiratory tract, this molecular defect causes obstruction of the airways by mucus and chronic endobronchial infection. The majority of patients suffer early death from chronic respiratory disease. Pseudomonas aeruginosa is the predominant chronic airway pathogen in older children and adults with CF and is associated with worse outcomes. However, overall survival in CF has been greatly improved in recent decades due in large part to the aggressive treatment of chronic infections such as P. aeruginosa. While intravenous and oral antibiotics are commonly used in the management of CF respiratory infections, inhaled anti-infective therapies offer the benefit of delivering the drug directly to the site of infection and avoiding potential toxicities associated with systemic absorption. Aztreonam lysine (AZLI) has recently been developed as an inhaled antibiotic for chronic use in CF patients with endobronchial $P$. aeruginosa infection. This paper reviews background data and the clinical studies which contributed to AZLI's formal FDA approval and growing role in the management of CF pulmonary disease.
\end{abstract}

Keywords: cystic fibrosis, aztreonam lysine, Pseudomonas aeruginosa, inhaled antibiotics

\section{Introduction}

Cystic fibrosis (CF) is the most common fatal genetic disorder affecting Caucasian populations. While $\mathrm{CF}$ is a multisystem disease involving the pancreas, liver, and gastrointestinal tract among other organs, most patient morbidity and mortality is related to advanced lung disease. Pulmonary manifestations of CF are characterized by chronic, recurring airway infection, inflammation, bronchiectasis, and progressively worsening obstructive lung physiology. Chronic respiratory failure is the most common cause of death. ${ }^{1}$

The overall life expectancy for patients suffering from CF has improved significantly over the last several decades, with mean survival now exceeding 35 years. ${ }^{2}$ Key factors in the management of $\mathrm{CF}$ which have led to improved outcomes include aggressive treatment of respiratory infections, daily chest physiotherapy combined with aerosolized medications (such as dornase alpha and hypertonic saline) aimed to improve clearance of mucus, and maximal treatment of comorbid conditions such as nutritional deficiency and CF-related diabetes mellitus. ${ }^{1,3}$

Pseudomonas aeruginosa is a common airway pathogen in $\mathrm{CF}$ and is associated with a decline in lung function and an overall increase in mortality. ${ }^{4,5}$ The majority of older adolescents and adults with CF are chronically infected with $P$. aeruginosa. ${ }^{2}$ Although aggressive use of antibiotic regimens at the earliest sign 
of $P$. aeruginosa infection may delay chronic airway colonization, $P$. aeruginosa is difficult or impossible to eradicate in most patients once colonization has occurred due to several factors such as reduced mucociliary clearance, altered innate immune defense mechanisms, compartmentalization of infection, biofilm production, and heterogeneous antibiotic resistance. ${ }^{3}$ Therefore the management of $P$. aeruginosa in CF lung disease is focused both on aggressive treatment during periods of acute illness and on chronic anti-infective maintenance strategies to help control endobronchial infection. ${ }^{6}$ Antibiotic agents with utility against $P$. aeruginosa can be administered via intravenous (IV), oral, and inhaled formulations. Each method has unique advantages (systemic therapeutic targeting for IV, convenience of oral and directed topical effect for inhaled therapies) and disadvantages (line access, treatment burden, and systemic toxicity for IV; minimal available agents and gastrointestinal intolerance for oral; and localized intolerance, potential long-term toxicity, and treatment burden for inhaled therapies).

Recently published guidelines recommend the regular use of inhaled tobramycin in patients with chronic $P$. aeruginosa infection, citing its proven benefits in improving lung function and decreasing exacerbations. ${ }^{7}$ Data from the US CF Foundation Patient Registry suggests that almost 70\% of eligible patients use inhaled tobramycin. ${ }^{2}$ However, the regular use of inhaled tobramycin may be limited in some patients by side effects, long-term toxicity, expense, and the treatment burden associated with time of administration. Additionally, there is ongoing concern for the emergence of antibiotic resistance and increasing MICs (minimum inhibitory concentrations) for $P$. aeruginosa isolates with chronic tobramycin exposure, of which the long-term clinical implications have not yet been elucidated. ${ }^{3}$ Therefore the development of alternative inhaled antibiotic therapies (such as aztreonam lysine, colistin/colistimethate, liposomal amikacin, ciprofloxacin, levofloxacin, and fosfomycin) for use in CF has been an area of significant focus.

Aztreonam is a monobactam antibiotic with excellent coverage of aerobic Gram-negative bacterial species including $P$. aeruginosa. It has been available in IV formulation for decades, but aztreonam lysine (AZLI) was recently developed in an inhaled formulation to be delivered with a novel and potentially more patient-friendly nebulizer device. While aztreonam is traditionally considered to have strictly Gram-negative coverage, an early study of AZLI suggests that limited activity may exist for some strains of Staphylococcus aureus. ${ }^{8}$ The purpose of this paper is to review AZLI's development and the existing clinical data supporting its use for the management of chronic airway infection in CF.

\section{Pathogenesis of CF}

Over the past several decades much has been learned about the molecular basis of CF. ${ }^{9}$ It is an autosomal recessive disease whereby mutations in the gene encoding the cystic fibrosis transmembrane conductance regulator protein (CFTR) on chromosome 7 lead to defective or insufficient CFTR. ${ }^{10}$ Research into mutations, modifying genes, and severity of disease is currently ongoing. ${ }^{1}$ The $\Delta \mathrm{F} 508$ mutation is the most prevalent CFTR mutation among the CF population; however, multiple gene mutations have been and are currently being identified, with 1876 listed in the CFTR Mutation Database as of April 2011.2,10,11 The CFTR protein is a chloride channel responsible for chloride transport across cell membranes. In the respiratory tract, abnormal ion flow across the respiratory epithelium results in an intracellular accumulation of chloride ions and ultimately depletion of chloride, sodium and water from the airway lumen. The airway surface liquid layer is decreased which leads to poor mucociliary clearance and the development of thick, viscous mucus. ${ }^{1,9}$ The molecular pathway of CF results in an airway environment where bacteria can survive and thrive. Over time, chronic endobronchial infection and inflammation result in disruption of the airway epithelium and bronchiectasis. The physiologic consequence is progressive obstructive lung physiology, respiratory insufficiency, and death from chronic respiratory failure in the vast majority of patients (Figure 1).

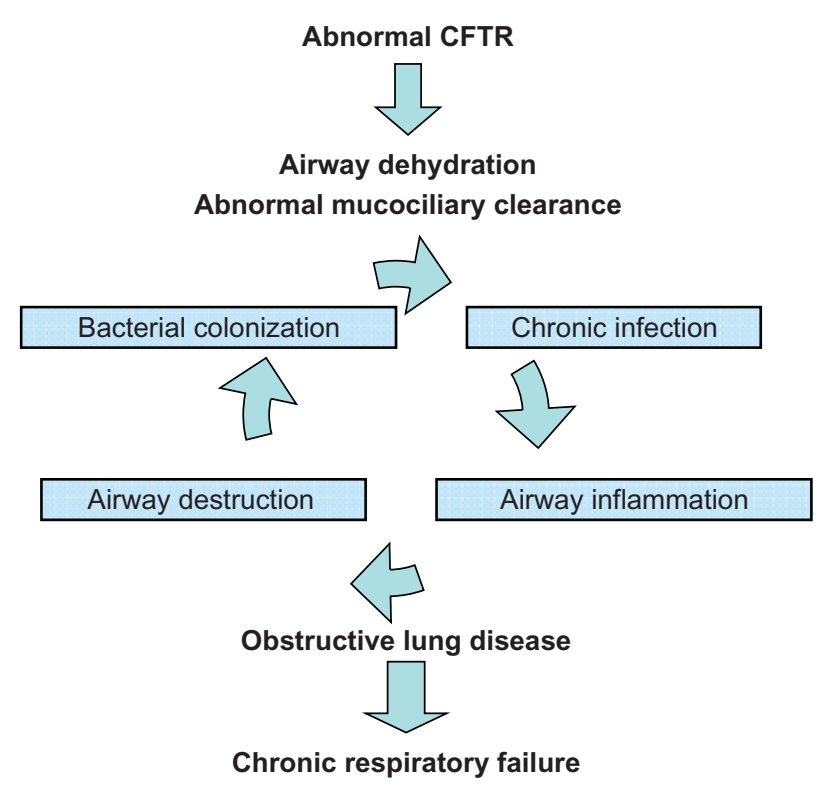

Figure I Mechanism of CF pulmonary disease.

Abbreviation: CFTR, cystic fibrosis transmembrane conductance regulator protein. 


\section{CF microbiology and the importance of $P$. aeruginosa}

Patients with $\mathrm{CF}$ acquire chronic airway microbial pathogens in a predictable manner (Figure 2). Early in childhood, the most common pathogens include $S$. aureus and Haemophilus influenzae. As patients transition through adolescence to adulthood, P. aeruginosa becomes the most prevalent endobronchial infection, with approximately $80 \%$ of adults having consistent positive cultures from the respiratory tract. ${ }^{2}$

The acquisition of $P$. aeruginosa is an important event in the natural history of CF lung disease, as chronic $P$. aeruginosa infection is associated with both a decrease in lung function and lower overall survival. ${ }^{4}$ This profound clinical consequence is associated with a transition from a nonmucoidal to mucoidal phenotype, and the subsequent development of biofilms and a resultant increase in bacterial virulence and multidrug resistance. ${ }^{12}$

\section{Inhaled antibiotics in CF}

Administration of antibiotic agents directly into the airways of patients with CF offers several potential benefits. The desired drug can reach the target area of infection without involving the systemic circulation. This may avoid issues with nephrotoxicity, ototoxicity, and other problems commonly associated with various IV antipseudomonal agents such as aminoglycosides (gentamicin, tobramycin, and amikacin) and colistin. Furthermore, the concentration of drug in the airway itself may reach levels which exceed the MIC, thereby offering clinical efficacy even though a particular agent may be "resistant" on standard drug susceptibility testing.

Common side effects associated with inhaled antibiotic agents include manifestations of bronchospasm such as wheezing, chest tightness or cough, throat discomfort, and hoarseness. Side effects can be related to patient-specific sensitivity (idiosyncratic or sensitization with chronic use), drug formulation ( $\mathrm{pH}$, chemical properties, excipients, esthetic quality), and drug delivery methods (particulate size nebulization devices). Achievement of optimal particle sizes $(1-5 \mu \mathrm{m})$ for delivery to the small conducting airways is dependent on airway anatomy, minute ventilation, nebulization device, and nebulized flow rate. ${ }^{13,14}$ Traditional methods for delivery of aerosolized agents, which include jet and ultrasonic nebulizers, may take 20-30 minutes for one treatment and, therefore, result in a substantial treatment burden for individual patients.

Inhaled tobramycin was the first inhaled antibiotic specifically approved for the treatment of $P$. aeruginosa infection in CF. It is clinically available in a pre-mixed

Age Specific Prevalence of Respiratory Organisms, 2009

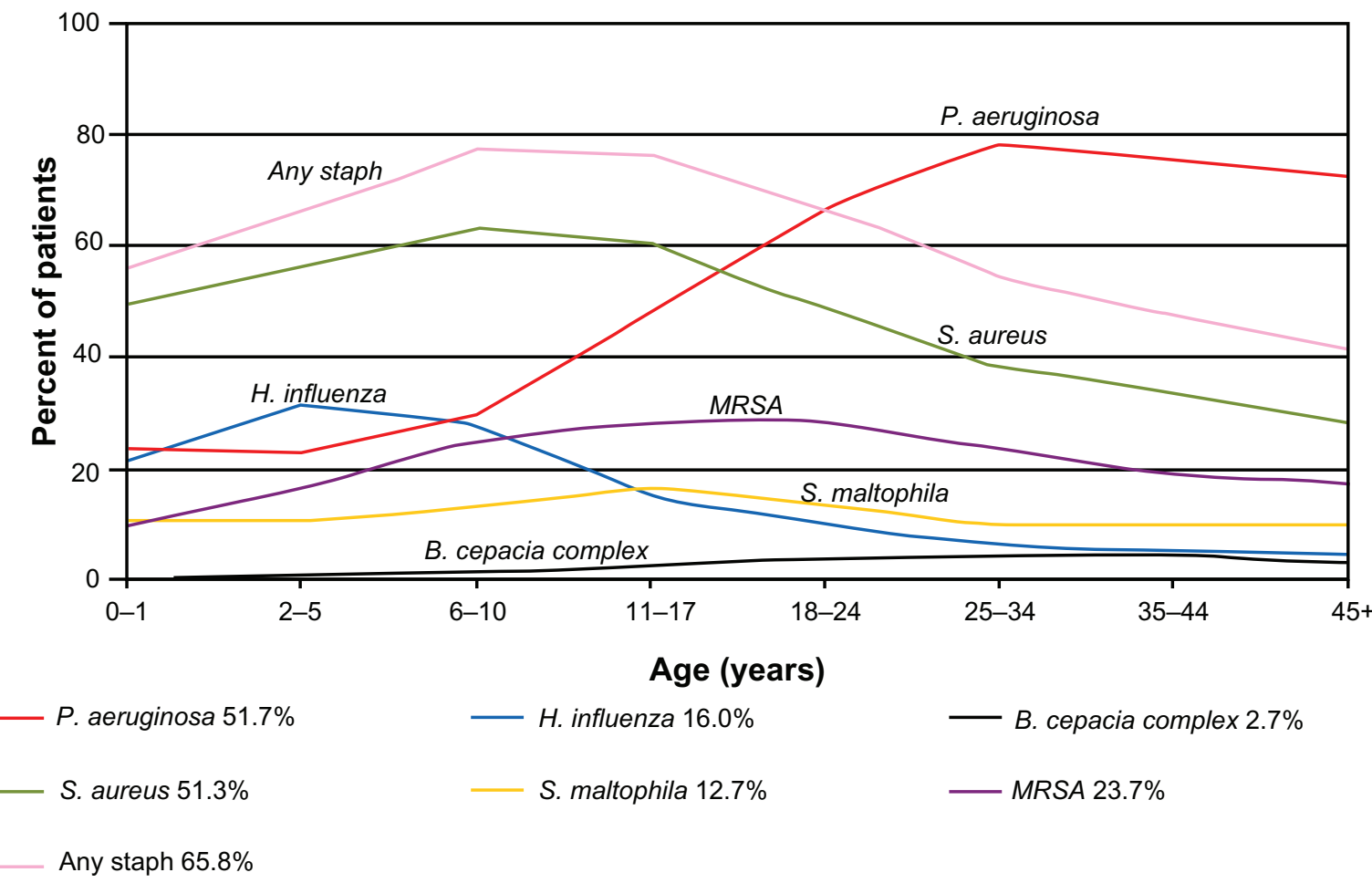

Figure 2 Prevalence of endobronchial infection.

Reproduced with permission by Cystic Fibrosis Foundation Patient Registry, 2009 Annual Data Report, Bethesda, MD. ${ }^{2}$ @) 201 I Cystic Fibrosis Foundation. Abbreviation: MRSA, methicillin-resistant S.aureus. 
$300 \mathrm{mg} / 5 \mathrm{~mL}$ vial $\left(\mathrm{TOBI}^{\circledR}\right.$, Novartis Pharmaceuticals, Basel, Switzerland) for twice daily use. Inhaled tobramycin has widespread use, a favorable side effect profile, and proven efficacy including improvement in lung function and decreased need for hospitalizations. ${ }^{15}$ Standard guidelines recommend its use on an alternating on-off 4-week cycle for patients with chronic $P$. aeruginosa infection to reduce exacerbations and improve lung function. ${ }^{7}$ Additionally, alternating cycles have been favored historically as an effort to minimize development of tobramycin resistance, namely bacterial impermeability, with chronic therapy. ${ }^{16}$ Many centers will also use it in combination with oral or IV antibiotics in the treatment of acute pulmonary exacerbations, however there is no clear medical literature to support this practice. ${ }^{14,17}$ Side effects which can be associated with inhaled tobramycin include hoarseness and tinnitus. Long-term use may also have cumulative effects on ototoxicity and nephrotoxicity.

Colistin has also been commonly used to treat chronic endobronchial $P$. aeruginosa infection, particularly in Europe. ${ }^{18}$ One trial comparing inhaled colistin to inhaled tobramycin found a greater improvement in lung function with tobramycin, but both drugs were well-tolerated. ${ }^{19}$ Colistin must be dispensed in powder form and mixed into aqueous solution at the time of administration, as toxicity from pre-mixed solution has been reported. ${ }^{20}$ Aerosolization of standard IV amikacin has also been utilized in $\mathrm{CF}^{21}$, and may be particularly useful in the chronic treatment of Mycobacterium abscessus. ${ }^{22}$

\section{Aztreonam}

Aztreonam is a monobactam antibiotic developed in the early 1980s. It has excellent activity against a wide range of Gram-negative organisms, including $P$. aeruginosa..$^{23,24}$ Aztreonam binds to penicillin-binding proteins and causes inhibition of bacterial cell wall synthesis and ultimately death of the bacterial cell. The respiratory tract receives good penetrance, ${ }^{25}$ and several studies have demonstrated both in vitro and clinical evidence of benefits of intravenous aztreonam in patients with $\mathrm{CF}^{26-28}$ Aztreonam's utility against P. aeruginosa and potentially other Gram-negative organisms that may be associated with $\mathrm{CF}$ endobronchial infections (such as Burkholderia cepacia complex [BCC]) make it an attractive antibiotic to be developed in inhaled formulations.

Potential side effects of IV aztreonam include rash, nausea, vomiting, diarrhea, and elevation of liver enzymes. The IV aztreonam formulation contains the arginine salt which has the clinical potential to worsen airway inflammation or cause bronchoconstriction. Arginine is a substrate for nitric oxide production which has been associated with airway inflammation in asthma. ${ }^{29,30}$ However, data are conflicting in CF. Nitric oxide formation has been shown to be reduced in $\mathrm{CF}$ airways which may lead to airway obstruction, and inhaled L-arginine has been investigated as a therapeutic approach in $\mathrm{CF}$ to improve exhaled nitric oxide and lung function. ${ }^{31}$ Due to uncertainty in nitric oxide balance in individual CF patients needing to avoid excessive nitric oxide formation, the lysine salt was chosen as a potentially safer formulation of aztreonam for aerosolized use. ${ }^{8}$

\section{Delivery device for inhaled aztreomam}

AZLI (Cayston ${ }^{\circledR}$; Gilead Sciences, Foster City, CA) has been specifically developed for use with the Altera ${ }^{\circledR}$ Nebulizer System which uses eFlow ${ }^{\circledR}$ electronic nebulizer technology (both from Pari Innovative Manufacturers Inc, Midlothian, VA). There are several potential benefits of drug delivery via this electronic, multi-use nebulizer device. The eFlow ${ }^{\circledR}$ utilizes a vibrating, perforated membrane to generate a highspeed aerosol. With this novel aerosolization format, AZLI particle generation is reported as $3.6 \pm 0.1 \mu \mathrm{m}^{26}$ which is in the optimal range of particulate size for delivery to the small conducting airways $(1-5 \mu \mathrm{m}){ }^{11,13}$ Highly efficient delivery is achieved as a $1 \mathrm{~mL}$ dosage volume delivered over approximately 2-3 minutes, a delivery rate two to four times that of traditional high-quality jet nebulizers. ${ }^{8}$ These features may improve patient satisfaction and overall compliance.

\section{Clinical studies of inhaled aztreonam}

AZLI was developed and systematically evaluated by a collaborative, international effort over the past decade. These studies are summarized in Table 1. Initial pre-clinical data and Phase 1 study results were reported by Gibson and colleagues in $2006 .{ }^{8}$ A total of 18 adult and 17 adolescent patients with a forced expiratory volume over 1 second $\left(\mathrm{FEV}_{1}\right) \geq 40 \%$ predicted were randomized to receive AZLI vs placebo in daily escalating doses to determine the bioactivity of the drug in sputum; systemic and sputum pharmacokinetics; in vitro microbiological activity; and clinical safety. AZLI was well-tolerated at doses of $75 \mathrm{mg}, 150 \mathrm{mg}$, and $225 \mathrm{mg}$. Sputum drug concentrations exceeded the $\mathrm{MIC}_{50}$ against multidrug resistant $P$. aeruginosa as well as BCC for 4 hours after drug administration. Systemic absorption was minimal in adult patients receiving the $75 \mathrm{mg}$ dose (Cmax $0.419 \pm 0.155 \mu \mathrm{g} / \mathrm{mL}$ ). This work provided the background for further clinical development of AZLI. 
Table I Summary of AZLI clinical trials

\begin{tabular}{|c|c|c|c|c|}
\hline Author & $\begin{array}{l}\text { Patient } \\
\text { population }\end{array}$ & $\begin{array}{l}\text { Study } \\
\text { design }\end{array}$ & $\begin{array}{l}\text { Primary } \\
\text { endpoint }\end{array}$ & $\begin{array}{l}\text { Main } \\
\text { results }\end{array}$ \\
\hline I. Gibson et $\mathrm{al}^{8}$ & $\begin{array}{l}-35 \text { adult and } \\
\text { adolescents } \\
-\mathrm{FEV}_{1} \geq 40 \%\end{array}$ & $\begin{array}{l}\text { Phase I, double-blind, } \\
\text { placebo-controlled, } \\
\text { dose-escalation trial }\end{array}$ & $\begin{array}{l}\text { Pharmacokinetics } \\
\text { and tolerability }\end{array}$ & $\begin{array}{l}\text { AZLI was well tolerated } \\
\text { and sputum concentrations } \\
\text { exceeded } \mathrm{MIC} \text { of } \mathrm{Pa}\end{array}$ \\
\hline $\begin{array}{l}\text { 2. Retsch-Bogart } \\
\text { et } \mathrm{al}^{32}\end{array}$ & $\begin{array}{l}-105 \text { patients, } \\
\text { age } \geq 13 \text { years } \\
- \text { FEV }_{1} \geq 40 \%\end{array}$ & $\begin{array}{l}\text { Phase II, randomized, } \\
\text { double-blind, } \\
\text { placebo-controlled trial } \\
\text { of AZLI vs placebo for } 14 \text { days }\end{array}$ & $\begin{array}{l}\text { Percent change } \\
\text { in FEV, at end } \\
\text { of } 14 \text { days }\end{array}$ & $\begin{array}{l}\text { - No significant change in FEV } \\
\text { - Trend of greater improvement in lung } \\
\text { function in those with worse baseline FEV, } \\
\text { - } 75 \mathrm{mg} \text { dose determined to be ideal }\end{array}$ \\
\hline 3. McCoy et $\mathrm{al}^{34}$ & $\begin{array}{l}-246 \text { patients, } \\
\text { age } \geq 6 \text { years } \\
- \text { FEV, } 25 \%-75 \%\end{array}$ & $\begin{array}{l}\text { Phase II, randomized, } \\
\text { double-blind, } \\
\text { placebo- controlled trial } \\
\text { of AZLI vs placebo for } 28 \text { days }\end{array}$ & $\begin{array}{l}\text { Time to need for } \\
\text { additional anti-Pa } \\
\text { antibiotics }\end{array}$ & $\begin{array}{l}\text { - Increased time to need for additional anti- } \\
\text { Pa antibiotics } \\
\text { - Improved } \mathrm{FEV} \text {, patient symptoms score, } \\
\text { sputum } \mathrm{Pa} \text { density }\end{array}$ \\
\hline $\begin{array}{l}\text { 4. Retsch-Bogart } \\
\text { et } \mathrm{al}^{35}\end{array}$ & $\begin{array}{l}-164 \text { patients, } \\
\text { age } \geq 6 \text { years } \\
-F E V, 25 \%-75 \%\end{array}$ & $\begin{array}{l}\text { Phase II, randomized, } \\
\text { double-blind, } \\
\text { placebo-controlled trial } \\
\text { of AZLI vs placebo for } 28 \text { days }\end{array}$ & $\begin{array}{l}\text { Change in } \\
\text { patient-reported } \\
\text { respiratory } \\
\text { symptom score }\end{array}$ & $\begin{array}{l}\text { - Significant improvement in self-reported } \\
\text { symptom scores } \\
\text { - Improved FEV, and sputum Pa density }\end{array}$ \\
\hline 5. Oermann et $\mathrm{al}^{36}$ & $\begin{array}{l}-274 \text { patients, } \\
\text { age }>8 \text { years } \\
\text { (mean age } 28.5 \text { ) } \\
\text {-previous participant } \\
\text { in study } 3 \text { or } 4\end{array}$ & $\begin{array}{l}\text { Phase III, I } 8 \text { month open label } \\
\text { trial evaluating long-term use } \\
\text { of alternating months of AZLI }\end{array}$ & $\begin{array}{l}\text { Safety } \\
\text { and efficacy }\end{array}$ & $\begin{array}{l}\text { - Long-term use was well tolerated } \\
\text { - At the end of each treatment cycle, } \\
\text { improved } \mathrm{FEV}_{1} \text {, symptom scores, } \\
\text { sputum } \mathrm{Pa} \text { density } \\
\text { - Improved weight over treatment course }\end{array}$ \\
\hline $\begin{array}{l}\text { 6. Wainwright } \\
\text { et } \mathrm{al}^{37}\end{array}$ & $\begin{array}{l}-157 \text { patients, } \\
\text { age } \geq 6 \text { years } \\
-\mathrm{FEV}_{1}>75 \%\end{array}$ & $\begin{array}{l}\text { Randomized, double-blind, } \\
\text { placebo-controlled trial } \\
\text { of AZLI vs placebo for } 28 \text { days }\end{array}$ & $\begin{array}{l}\text { Change in } \\
\text { patient-reported } \\
\text { respiratory } \\
\text { symptom score }\end{array}$ & $\begin{array}{l}\text { - No significant change in symptom score } \\
\text { - Improved } \mathrm{FEV}_{1} \text { and sputum } \mathrm{Pa} \text { density }\end{array}$ \\
\hline
\end{tabular}

Abbreviations: $\mathrm{Pa}$, Pseudomonas aeruginosa; $\mathrm{FEV}_{1}$, forced expiratory volume in I second; AZLI, aztreonam lysine.

A Phase II investigation of AZLI was reported by Retsch-Bogart and colleagues. ${ }^{32}$ In this double-blind, randomized, placebo-controlled multicenter trial involving 20 US CF centers, patients with mild and moderate lung disease were recruited to evaluate the safety, tolerability and efficacy of AZLI over a 14-day treatment period. A total of 105 adult and adolescent patients with $\mathrm{FEV}_{1} \geq 40 \%$ predicted were randomized to receive AZLI twice daily at doses of $75 \mathrm{mg}$ or $225 \mathrm{mg}$ vs placebo. The primary outcome of the study was percent change in $\mathrm{FEV}_{1}$ at day 14 in the patients receiving $225 \mathrm{mg}$ of AZLI twice daily. There was no significant change in this variable. However, secondary analysis determined that there was a trend of greater improvement in lung function in those individuals with lower baseline lung function. AZLI was well tolerated in general, with slightly more adverse events (primarily cough) associated with higher treatment dose. Peak serum concentrations of AZLI were substantially lower, with a median peak of 0.69 $(0.02-1.74) \mu \mathrm{g} / \mathrm{mL}$ in the $75 \mathrm{mg}$ group and median peak of $1.49(0.01-3.84) \mu \mathrm{g} / \mathrm{mL}$ in the $225 \mathrm{mg}$ group, ${ }^{27}$ than those of a single $500 \mathrm{mg}$ intravenous administration $(54 \mu \mathrm{g} / \mathrm{mL}) .^{33}$ Median sputum concentrations (279 [22.6-1290] $\mu \mathrm{g} / \mathrm{g}$ in the $75 \mathrm{mg}$ group and 900 [80.2-5689] $\mu \mathrm{g} / \mathrm{g}$ in the $225 \mathrm{mg}$ group) were significantly above the $\mathrm{MIC}_{50}$ for $P$. aeruginosa isolates $(\leq 1 \mu \mathrm{g} / \mathrm{mL}$ and $4 \mu \mathrm{g} / \mathrm{mL}$ in the $75 \mathrm{mg}$ and $225 \mathrm{mg}$ groups, respectively), and treatment with the study drug was not associated with new endobronchial pathogens. This study is significant in that it led investigators to focus on $75 \mathrm{mg}$ dosing for further clinical trials.

McCoy and colleagues described the results of another Phase II, multicenter trial evaluating the utility of AZLI in patients with moderate-to-severe CF lung disease already on treatment with cyclical months of inhaled tobramycin. ${ }^{34}$ Patients with chronic P. aeruginosa infection aged 6 years and older with baseline $\mathrm{FEV}_{1}$ values between $25 \%$ and $75 \%$ of predicted values were enrolled from 56 US CF centers. Other significant inclusion criteria included at least three monthly courses of inhaled tobramycin in the year before the study and room air oxygen saturations $\geq 90 \%$ on room air. Patients with BCC or on chronic oral corticosteroids were excluded. Randomization occurred in a 1:1:1 fashion to three study groups: AZLI $75 \mathrm{mg}$ twice daily; AZLI $75 \mathrm{mg}$ three times daily; or placebo. The primary study endpoint was time to need additional antipseudomonal antibiotics for treatment of symptoms of a pulmonary exacerbation. Secondary endpoints included change in clinical symptoms, pulmonary function testing, time to hospitalizations, total number of hospitalizations, weight, and P. aeruginosa density in sputum. 
A total of 246 individuals were enrolled in the study. After randomization, all patients received an open-labeled 28 -day run-in treatment course with inhaled tobramycin. The patients were generally adults (mean age 26.2 years) with moderately to severely impaired lung function (mean $\mathrm{FEV}_{1}$ $55.1 \%$ predicted), who had averaged over five courses of inhaled tobramycin in the year before the study. Drop-out rate in the study was high, with 35 patients discontinuing the study during the tobramycin run-in period (mostly due to adverse events), leaving 211 patients for intention-to-treat analysis. Of this group, 173 completed the AZLI/placebo treatment period, but only 90 patients fully completed the trial. The primary reasons for discontinuation of study therapy were adverse events (mostly related to cough and other expected CF-related symptoms) which were not statistically significant between groups. ${ }^{28}$

The efficacy of AZLI was demonstrated by a 21-day increase in the median time to need additional antipseudomonal antibiotics in the pooled AZLI treatment groups vs those receiving placebo. Patient-reported symptom scores, mean $\mathrm{FEV}_{1}$ after treatment, and P. aeruginosa density were all significantly improved in the AZLI treatment groups. AZLI was generally well tolerated with no difference in adverse events between placebo and treatment groups. ${ }^{28}$

Retsch-Bogart and colleagues then reported a Phase II, randomized, double-blind, placebo-controlled study involving $53 \mathrm{CF}$ centers in Australia, New Zealand, Canada, and the US. ${ }^{35}$ Whereas McCoy's study evaluated AZLI in patients generally adherent to chronic CF therapies aimed at P. aeruginosa, this study specifically evaluated its effectiveness in patients receiving less maintenance therapies than standard guidelines recommend.

A total of 164 patients aged 6 years and older with chronic P. aeruginosa infection and $\mathrm{FEV}_{1}$ between $25 \%$ and $75 \%$ of predicted were randomized in a 1:1 manner to receive AZLI $75 \mathrm{mg}$ TID or placebo for 28 days. Monitoring occurred for 14 days following the treatment period. The primary endpoint was change in patient-reported respiratory symptoms as evaluated by the CF Questionnaire-Revised (CFQ-R) respiratory scale. Change in lung function, sputum $P$. aeruginosa density, and key nonrespiratory CFQ-R scores were secondary endpoints. ${ }^{29}$

Following 28 days of treatment, when compared to placebo, patients receiving AZLI had a significant improvement in mean CFQ-R scores. Furthermore, lung function improved and sputum P. aeruginosa density decreased during the treatment period. Adverse events were minimal and consistent with standard symptoms of $\mathrm{CF}^{29}$
Oermann and colleagues next reported a Phase II study evaluating the long-term safety and efficacy of AZLI. ${ }^{36}$ This was an international 18-month open-label study which evaluated AZLI when used in alternating month cycles. Patients from $71 \mathrm{CF}$ centers who participated in the previously described Phase II trials were eligible to participate. Study patients completed up to nine cycles ( 28 days on and 28 days off) of AZLI with dosages of either $75 \mathrm{mg}$ twice daily or three times daily, consistent with the dosing arm they had been assigned in their previous study. A total of 274 patients participated, with a mean age of 28.5 years.

Overall, long-term cyclical AZLI use was well tolerated, with the most common adverse events or side effects being consistent with expected CF symptoms. At the end of each treatment cycle, patients demonstrated improved $\mathrm{FEV}_{1}$, improved symptoms as measured by mean CFQ-R respiratory scores, and decreases in sputum P. aeruginosa density. Overall, patients maintained excellent adherence to long-term AZLI use $(92 \%$ in the twice daily group and $88 \%$ in the three times daily group). Patients also demonstrated a sustained weight gain across the time frame of the study period. ${ }^{30}$

Most recently, Wainwright and colleagues described the results of a double-blind, multicenter, randomized, placebocontrolled trial which evaluated the use of AZLI in CF patients with mild lung disease, defined by $\mathrm{FEV}_{1}>75 \%$ of predicted. ${ }^{37} \mathrm{~A}$ total of 157 patients age 6 years and older were recruited from the US, Canadian, and Australian centers. They were randomized to receive AZLI $75 \mathrm{mg}$ three times daily vs placebo for 28 days with a 14-day follow-up period. The primary outcome measure was change from baseline in self-reported symptom scores as measured by the CFQ-R. Key secondary endpoints were change in lung function, change in sputum $P$. aeruginosa density, and use of additional antipseudomonal antibiotics.

While there was no significant difference in patient symptom scores, patients treated with AZLI had a significant decrease in sputum $P$. aeruginosa density and also a higher $\mathrm{FEV}_{1}$ at day 28. This change in lung function resulted primarily from a decline in lung function among those receiving placebo. Furthermore, subanalysis of the primary endpoint among treatment groups revealed larger treatment effects in adult patients and those with baseline $\mathrm{FEV}_{1}<90 \%$ predicted as compared to those with $\mathrm{FEV}_{1} \geq 90 \%$ predicted. AZLI was well tolerated in this study. ${ }^{31}$

\section{Ongoing and future $A Z L I$ studies}

While the benefits of AZLI in patients with chronic P. aeruginosa infection have been demonstrated in multiple 
clinical trials, what remains to be determined is whether or not AZLI may benefit CF patients with other forms of endobronchial infection. For example, there is a clear need for additional therapies to treat patients infected with BCC, a particularly virulent Gram-negative infection characterized by multidrug resistance. ${ }^{38,39}$ The initial study of AZLI demonstrated in vitro activity against $\mathrm{BCC},{ }^{8}$ and a Phase III clinical trial is ongoing to further evaluate the potential benefit of AZLI in this unique CF patient population (ClinicalTrials.gov Identifier: NCT010595). AZLI may also have potential benefits in other subsets of CF patients. For instance, a trial is planned evaluating AZLI's effectiveness as part of an early eradication treatment regimen for $\mathrm{CF}$ patients at the initial identification of $P$. aeruginosa infection. Finally, whether AZLI offers clinical benefit for the treatment of acute CF respiratory exacerbations needs to be determined by prospective studies.

\section{Conclusions}

As a result of extensive international evaluations demonstrating consistent beneficial effects on lung function, patient-reported symptom scores, and other clinical measures such as the need for additional antipseudomonal antibiotics, AZLI was approved by the US Food and Drug Administration in 2010 for the treatment of chronic P. aeruginosa infection in patients with $\mathrm{CF}^{40}$ The use of AZLI has been well accepted by many CF centers for use as an alternating on-off month cycle. A clear potential benefit for individual patients is the shorter duration of drug administration, thus resulting in less treatment burden and the potential for improved adherence. From the available clinical studies, it is reasonable to conclude that cycling monthly AZLI as mono-inhaled therapy, or as add-on therapy to other cyclical inhaled antibiotics such as tobramycin or colistin, may be both a clinically efficacious and well-tolerated therapy. At this time, since there are no available comparative efficacy studies, the decision to initiate a particular inhaled antibiotic therapy should be made based on available antibiotic sensitivity data for P. aeruginosa, patient-specific historical response to various inhaled antibiotic therapies, and patient preference for delivery method.

\section{Disclosure}

Stephen Kirkby and Kimberley Novak report no conflicts of interest in this work. Karen McCoy has received a Gilead grant, is a board member of the Cystic Fibrosis Foundation, and has received or has grants pending from Vertex
Pharmaceuticals, Mpex Pharmaceuticals, FDA, ALA, CFFT, and Novartis Pharmaceuticals, although these do not relate directly to the current work.

\section{References}

1. Davis PB. Cystic fibrosis since 1938. Am J Respir Crit Care Med. 2006;173(5):475-482.

2. Cystic Fibrosis Foundation Patient Registry. 2009 Annual Data Report. Bethesda MD: (2011 Cystic Fibrosis Foundation. http://www.cff.org/ UploadedFiles/research/ClinicalResearch/Patient-Registry-Report2009.pdf.

3. Gibson RL, Burns JL, Ramsey BW. Pathophysiology and management of pulmonary infections in cystic fibrosis. Am J Respir Crit Care Med. 2003;168(8):918-951.

4. Emerson J, Rosenfeld M, McNamara S, Ramsey B, Gibson RL. Pseudomonas aeruginosa and other predictors of mortality and morbidity in young children with cystic fibrosis. Pediatr Pulmonol. 2002;34(2):91-100.

5. Rosenfeld M, Gibson RL, McNamara S, et al. Early pulmonary infection, inflammation, and clinical outcomes in infants with cystic fibrosis. Pediatr Pulmonol. 2001;32(5):356-366.

6. Kirkby S, Novak K, McCoy K. Update on antibiotics for infection control in cystic fibrosis. Expert Rev Anti Infect Ther. 2009;7(8):967-980.

7. Flume PA, Mogayzel PJ Jr, Robinson KA, et al. Cystic fibrosis pulmonary guidelines: treatment of pulmonary exacerbations. Am J Respir Crit Care Med. 2009;180(9):802-808.

8. Gibson RL, Retsch-Bogart GZ, Oermann C, et al. Microbiology, safety, and pharmacokinetics of aztreonam lysinate for inhalation in patients with cystic fibrosis. Pediatr Pulmonol. 2006;41(7):656-665.

9. Rowe SM, Miller S, Sorscher EJ. Cystic fibrosis. $N$ Engl J Med. 2005;352(19):1992-2001.

10. Zielenski J, Tsui LC. Cystic fibrosis: genotypic and phenotypic variations. Аnпu Rev Genet. 1995;29:777-807.

11. Cystic fibrosis mutation database. Available at: http://www.genet.sick kids.on.ca/StatisticsPage.html. Last updated April 25, 2011. Accessed July 8, 2011.

12. Li Z, Kosorok MR, Farrell PM, et al. Longitudinal development of mucoid Pseudomonas aeruginosa infection and lung disease progression in children with cystic fibrosis. JAMA. 2005;293(5):581-588.

13. Kuhn RJ. Formulation of aerosolized therapeutics. Chest. 2001;120 (Suppl 3):94S-98S.

14. Toso C, Williams DM, Noone PG. Inhaled antibiotics in cystic fibrosis: a review. Ann Pharmacother. 1996;30(7-8):840-850.

15. Ramsey BW, Pepe MS, Quan JM, et al. Intermittent administration of inhaled tobramycin in patients with cystic fibrosis. Cystic Fibrosis Inhaled Tobramycin Study Group. N Engl J Med. 1999;340(1):23-30.

16. LiPuma JJ. Microbiological and immunologic considerations with aerosolized drug delivery. Chest. 2001;120(Suppl 3):118S-123S.

17. Ryan G, Singh M, Dwan K. Inhaled antibiotics for long-term therapy in cystic fibrosis. Cochrane Database Syst Rev. 2011;(3):CD001021.

18. Reed MD, Aronoff SC, Stern RC, et al. Single-dose pharmacokinetics of aztreonam in children with cystic fibrosis. Pediatr Pulmonol. 1986;2(5):282-286.

19. Hodson ME, Gallagher CG, Govan JR. A randomised clinical trial of nebulised tobramycin or colistin in cystic fibrosis. Eur Respir J. 2002;20(3):658-664.

20. McCoy KS. Compounded colistimethate as possible cause of fatal acute respiratory distress syndrome. $N$ Engl J Med. 2007;357(22):2310-2311.

21. Schaad UB, Wedgwood-Krucko J, Suter S, Kraemer R. Efficacy of inhaled amikacin as adjunct to intravenous combination therapy (ceftazidime and amikacin) in cystic fibrosis. J Pediatr. 1987;111(4):599-605.

22. Kirkby S, Astor T, Patel A, Novak K, McCoy K. Treatment of mycobacterium abscessus lung disease: A single center experience. Am J Respir Crit Care Med. 2009;179(1):A4085. 
23. Sykes RB, Bonner DP, Bush K, Georgopapadakou NH. Azthreonam (SQ 26,776), a synthetic monobactam specifically active against aerobic Gram-negative bacteria. Antimicrob Agents Chemother. 1982;21(1):85-92.

24. Brewer NS, Hellinger WC. The monobactams. Mayo Clin Proc. 1991;66(11):1152-1157.

25. Bechard DL, Hawkins SS, Dhruv R, Friedhoff LT. Penetration of aztreonam into human bronchial secretions. Antimicrob Agents Chemother. 1985;27(2):263-264.

26. Aronoff SC, Klinger JD. In vitro activities of aztreonam, piperacillin, and ticarcillin combined with amikacin against amikacin-resistant Pseudomonas aeruginosa and P. cepacia isolates from children with cystic fibrosis. Antimicrob Agents Chemother. 1984;25(2):279-280.

27. Bosso JA, Black PG, Matsen JM. Efficacy of aztreonam in pulmonary exacerbations of cystic fibrosis. Pediatr Infect Dis J. 1987;6(4):393-397.

28. Bosso JA, Black PG. Controlled trial of aztreonam vs tobramycin and azlocillin for acute pulmonary exacerbations of cystic fibrosis. Pediatr Infect Dis J. 1988;7(3):171-176.

29. Dietzsch HJ, Gottschalk B, Heyne K, Leupoid W, Wunderlich P. Cystic fibrosis: comparison of two mucolytic drugs for inhalation treatment (acetylcysteine and arginine hydrochloride). Pediatrics. 1975;55(1):96-100.

30. Sapienza MA, Kharitonov SA, Horvath I, Chung KF, Barnes PJ. Effect of inhaled L-arginine on exhaled nitric oxide in normal and asthmatic subjects. Thorax. 1998;53(3):172-175.

31. Grasemann H, Kurtz F, Ratjen F. Inhaled L-arginine improves exhaled nitric oxide and pulmonary function in patients with cystic fibrosis. Am J Respir Crit Care Med. 2006;174(2):208-212.
32. Retsch-Bogart GZ, Burns JL, Otto KL, et al. A phase 2 study of aztreonam lysine for inhalation to treat patients with cystic fibrosis and Pseudomonas aeruginosa infection. Pediatr Pulmonol. 2008;43(1):47-58.

33. Azactam ${ }^{\circledR}$ package insert. Princeton, NJ: Bristol-Myers Squibb, January 2010 .

34. McCoy KS, Quittner AL, Oermann CM, Gibson RL, Retsch-Bogart GZ, Montgomery AB. Inhaled aztreonam lysine for chronic airway Pseudomonas aeruginosa in cystic fibrosis. Am J Respir Crit Care Med. 2008;178(9):921-928.

35. Retsch-Bogart GZ, Quittner AL, Gibson RL, et al. Efficacy and safety of inhaled aztreonam lysine for airway pseudomonas in cystic fibrosis. Chest. 2009;135(5):1223-1232.

36. Oermann CM, Retsch-Bogart GZ, Quittner AL, et al. An 18-month study of the safety and efficacy of repeated courses of inhaled aztreonam lysine in cystic fibrosis. Pediatr Pulmonol. 2010;45(11):1121-1134.

37. Wainwright CE, Quittner AL, Geller DE, et al. Aztreonam for inhalation solution (AZLI) in patients with cystic fibrosis, mild lung impairment, and P. aeruginosa. J Cyst Fibros. 2011;10(4):234-242.

38. De Boeck K, Malfroot A, Van Schil L, et al. Epidemiology of Burkholderia cepacia complex colonisation in cystic fibrosis patients. Eur Respir J. 2004;23(6):851-856.

39. Courtney JM, Dunbar KE, McDowell A, et al. Clinical outcome of Burkholderia cepacia complex infection in cystic fibrosis adults. J Cyst Fibros. 2004;3(2):93-98.

40. US Food and Drug Administration. FDA Labeling information- Cayston. FDA Website [online]. Available at: http://www.accessdata.fda.gov/ drugsatfda_docs/label/2010/0508141bl.pdf.
Core Evidence

\section{Publish your work in this journal}

Core Evidence is an international, peer-reviewed open-access journal evaluating the evidence underlying the potential place in therapy of drugs throughout their development lifecycle from preclinical to postlaunch. The focus of each review is to evaluate the case for a new drug or class in outcome terms in specific indications and patient groups.

\section{Dovepress}

The manuscript management system is completely online and includes a very quick and fair peer-review system, which is all easy to use. Visit http://www.dovepress.com/testimonials.php to read real quotes from published authors. 